\title{
SIMULTANEOUS IMMOBILIZATION OF SOIL ARSENIC AND CADMIUM WITH REDUCED ACCUMULATION IN CABBAGE (BRASSICA OLERACEA L.) USING FE MODIFIED BIOCHAR
}

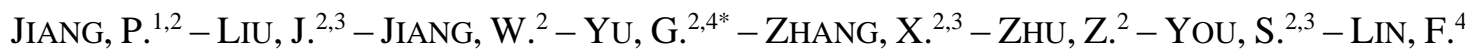 \\ ${ }^{1}$ Key Laboratory of Ecology of Rare and Endangered Species and Environmental Protection \\ (Guangxi Normal University), Ministry of Education, Guilin, China \\ ${ }^{2}$ College of Environmental Science and Engineering, Guilin University of Technology, Guilin, \\ China
${ }^{3}$ Technical Innovation Center of Mine Geological Environmental Restoration Engineering in Southern Karst Area, MNR, Nanning, China \\ ${ }^{4}$ Third Institute of Oceanography, Ministry of Natural Resources, Xiamen, China \\ *Corresponding author \\ e-mail:yguo2020@163.com; phone: +86-773-253-7332; fax: +86-773-589-5330
}

\begin{abstract}
Key Laboratory of Ecology of Rare and Endangered Species and Environmental Protection (Guangxi Normal University), Ministry of Education and Guilin University of Technology contributed equally to this work
\end{abstract}

(Received $5^{\text {th }}$ Feb 2021; accepted $9^{\text {th }}$ Apr 2021)

\begin{abstract}
Biochar (BC) has been widely studied as a soil amendment for immobilizing heavy metals in contaminated soil. However, the effect of modified biochar on arsenic (As) and cadmium (Cd) immobilization in soils and plant uptake rates are still unclear due to complex environmental interactions. To assess the effects of $\mathrm{Fe}_{2} \mathrm{O}_{3}, \mathrm{BC}$ and iron (Fe)-modified biochar (FMB) on the bioavailability of As and $\mathrm{Cd}$ in soil and their accumulation in cabbages (Brassica oleracea $\mathrm{L}$.), these values were investigated. The results indicated that the addition of $0.5 \%$ amendment to the soil significantly reduced the mobility of As/Cd in soil. Of the three soil amendments, FMB significantly reduced $\mathrm{As}$ and $\mathrm{Cd}$ accumulation in the cabbages by $27.4 \%$ and $30.1 \%$, respectively. This is achieved possibly by reducing the mobility of soil As/Cd, and as a result the available As/Cd were reduced by $12.3 \%$ and $7.94 \%$, respectively. The chemical forms of soil As/Cd may change from the available fraction to less available fractions, while the residual As/Cd increased by $16.3 \%$ and $353 \%$ compared to control, respectively. In summary, FMB demonstrated great potential in stabilizing As/Cd in the soil and in reducing the accumulation of $\mathrm{As} / \mathrm{Cd}$ in plants.
\end{abstract}

Keywords: Fe-modified biochar, heavy metal, immobilization, accumulation, bioavailability

\section{Introduction}

Heavy metal contamination in paddy soils is threatening human health in many parts of the world (Zhao et al., 2015). Co-contamination of As and $\mathrm{Cd}$ has raised public concern, especially in Southern China (Yu et al., 2016a; Qiao et al., 2018a). Both metals have great mobility and can accumulate in the human body through the food chain. The bioavailability of heavy metals in soils is directly related to their toxicity and the amount of accumulation in crops (Li et al., 2017; Kumarathilaka et al., 2018). In recent years, numerous methods have been investigated to reduce the soil bioavailability of As and $\mathrm{Cd}$, such as excavation, soil washing, and electrokinetics. However, these methods are prohibitively expensive and usually require intensive labor. Therefore, it is 
important to look for a cost-effective and environmentally friendly method to simultaneously immobilize As and Cd in the soil.

The application of biochar in remediating heavy metal contaminated soils has attracted much attention (Sneath et al., 2013). Biochar is a porous and fine-grained substance that is produced by the combustion of biomass under limited oxygen conditions. It has great adsorption abilities due to its porous structures, large specific surface area, high alkalinity, and special functional groups (Zhang et al., 2020). The results of previous studies have shown that the supplement of biochar significantly immobilized metals such as $\mathrm{Cd}$ in the soil through surface complexation, cation exchange, and metal precipitation (Venegas et al., 2016; Liang et al., 2017). For instance, the $\mathrm{Cd}$ accumulation in Indian mustard significantly decreased with biochar supplement (Park et al., 2011). As and Cd have almost opposite chemical behaviours in the soil (Al-Abed et al., 2007). Biochar addition in the soil can enhance the mobility of As, as it has a rich mineral ash content and increases the soil $\mathrm{pH}$. In addition, biochar enhances the formation of oxy-anions and thus promotes the mobility of As (Rocco et al., 2018). To increase the adsorption of As by the biochar, iron $(\mathrm{Fe})$ modified biochar was suggested. Studies have proven that Fe oxides, including goethite, hematite, ferrous, and Fe(II), influenced the bioavailability of As and $\mathrm{Cd}$ (Yu et al., 2017, 2016b). Fe-amendments reduce the bioavailability of As and increase the crystalline/crystalline Fe oxide-bound As through adsorption/desorption and co-precipitation with metal oxide (Yu et al., 2016b; Wen et al., 2020; Irshad et al., 2020). In addition, a reactive Fe (III) species is formed during the oxidation of Fe (II) to goethite. The reactive Fe (III) species is then able to interact with Fe-oxides and serve as the electron transfer from Fe (II) to goethite to form a reactive Fe (III) species as a reactive intermediate phase, which can interact with As (III) and lead to As (III) oxidation. Besides, Fe minerals and bacteriogenic Fe oxides produced by $\mathrm{Fe}$ (III)reducing bacteria and $\mathrm{Fe}(\mathrm{II})$-oxidizing microorganisms, respectively, can enhance the immobilization of Cd (Qiao et al., 2018b). Cabbage (Brassica chinensis L.) is an important vegetable in Asia, especially in China. Cabbage tends to absorb $\mathrm{Cd}$ from the soil, which poses a great risk for human health (Bashir et al., 2018). In general, Feamendment can reduce the bioavailability of As in the soil. Supplementation with biochar enhances As mobility but reduces $\mathrm{Cd}$ mobility. The immobilization effects of Fe-modified biochar (FMB) in As and Cd co-contaminated soil still remain largely unknown. Therefore, in order to obtain materials with the characteristics of both $\mathrm{Fe}$ oxides and biochar, we modified the biochar (FMB) by covering the surface with $\mathrm{Fe}$ oxides to study its effect on As and Cd bioavailability in As and Cd co-contaminated soil. Additionally, we compared the effects of FMB to $\mathrm{Fe}_{2} \mathrm{O}_{3}$ and biochar. Our aims were to (1) determine the best soil amendment concentrations by using a column experiment in As and $\mathrm{Cd}$ co-contaminated soil and (2) to identify the most suitable soil amendments by reducing the mobility of $\mathrm{As}$ and $\mathrm{Cd}$ in soils and reducing the accumulation of $\mathrm{As}$ and $\mathrm{Cd}$ in cabbages.

\section{Materials and methods}

\section{FMB preparation}

Bamboo (Phyllostachys pubescens) individuals were collected from the Yanshan campus of Guilin University of Technology, Guangxi, China. The bamboo stalks were cut into sizes of $30 \times 10 \times 3 \mathrm{~mm}^{3}$. The samples were heated in dilute ammonia $\left(\mathrm{NH}_{3}\right)$ 
solution $(5 \%)$ for $6 \mathrm{~h}$ to enhance the connectivity between the pores and cellular materials. The treated bamboo stalks were washed with deionized water three times and then dried at $80{ }^{\circ} \mathrm{C}$ for $24 \mathrm{~h}$. The dried samples were roasted at $600{ }^{\circ} \mathrm{C}$ for $3 \mathrm{~h}$. The samples were ground into power after cooling to room temperature. The dried samples were then soaked in a solution of iron (III) nitrate $\left(\mathrm{Fe}\left(\mathrm{NO}_{3}\right)_{3}\right)\left(1.2 \mathrm{~mol} \cdot \mathrm{L}^{-1}\right)$ for $5 \mathrm{~d}$. The $\mathrm{Fe}\left(\mathrm{NO}_{3}\right)_{3}$ solvent constituted a mixture of ethanol and ultra-pure water $(1: 1, \mathrm{v} / \mathrm{v})$ (Zhu et al., 2018). To ensure that all samples were soaked in the solution, we added some additional ethanol solution. The bamboo stalks were then dried at $80{ }^{\circ} \mathrm{C}$ for $24 \mathrm{~h}$. We repeated the process of soaking and drying for three times. Lastly, the samples were placed into a muffle device at $600{ }^{\circ} \mathrm{C}$ for $3 \mathrm{~h}$, following which we obtained the $\mathrm{BC}$ material.

\section{Characterization of FMB and BC}

We obtained the phase recognition of the BC and FMB by X-ray diffraction (XRD). The XRD analysis was carried out with copper Ka radiation at $40 \mathrm{kv}$ and $150 \mathrm{~mA}$. The morphological characters and chemical compositions of the BC and FMB were observed using scanning electron microscopy (SEM) and energy dispersive X-ray (EDS) spectroscopy, respectively (SEM-EDS, JEM-6380LV, JEOL, Tokyo, Japan). The tests of cyclic voltammetry (CV) and electrochemical impedance spectroscopy (EIS) were measured at the electrochemical workstation (CHI660E, Shanghai Chenhua Company, Shanghai, China). For CV, we scanned the potential from $-1.6 \mathrm{~V}$ to $0.8 \mathrm{~V}$ at a scan rate of 100, 300, and $500 \mathrm{mV} / \mathrm{s}$ in $0.1 \mathrm{M}$ degassed PBSS. We recorded impedance spectra in $0.1 \mathrm{M}$ phosphate-buffered saline (PBS) at $25^{\circ} \mathrm{C}$ within a frequency range from $10^{-2}$ to $10^{5} \mathrm{~Hz}$ with perturbation amplitude of $5 \mathrm{mV}$.

\section{Soil properties and plant preparation}

Two soils (soil 1 and soil 2) used in this study were collected from the topsoil (0-20 $\mathrm{cm}$ ) of different farmlands next to a smelter in Hechi, Guangxi. The soil properties have been influenced by smelting, wastewater irrigation, and open-pit mining, resulting in the soils being polluted in different degrees (Yu et al., 2020). The soils were placed in a room to air-dry at room temperature and then ground and sieved through 20- and 100mesh sieves before further use.

Cabbage seeds were purchased from the Yanshan Farmers Market, Guilin, Guangxi. The seeds were soaked for one night and then surface sterilized with a $10 \% \mathrm{H}_{2} \mathrm{O}_{2}$ solution for $10 \mathrm{~min}$. The seeds were sown into seedbeds filled with nutrient soil after rinsing with deionized water. The seedbeds were placed in a greenhouse, which the temperatures of the greenhouse were maintained at $25{ }^{\circ} \mathrm{C} /$ day and $18{ }^{\circ} \mathrm{C} /$ night. The relative humidity was about $75 \%$ with a $14 \mathrm{~h}$ photoperiod. We added deionized water to the soil to maintain the soil moisture content (about 50\%). After the seeds had germinated, we selected seedlings $6-8 \mathrm{~cm}$ high and with $2-3$ fronds for soil pot experiment 2 .

\section{Pot experiment}

Pot experiment 1: The effect of $\mathrm{Fe}_{2} \mathrm{O}_{3}, \mathrm{BC}$, and $\mathrm{FMB}$ on As and $\mathrm{Cd}$ mobility were studied in actual As/Cd-contaminated soil (soil 1). $\mathrm{Fe}_{2} \mathrm{O}_{3}, \mathrm{BC}$, and FMB were mixed completely with the soil samples. The mixed soil was placed into $2 \mathrm{~L}$ polypropylene pots (1.5 kg soil). We added $\mathrm{Fe}_{2} \mathrm{O}_{3}, \mathrm{BC}$, and $\mathrm{FMB}$ at concentrations of 0 (control), 
$0.2 \%, 0.5 \%$, and $1 \%(\mathrm{w} / \mathrm{w})$. The pots were then incubated in the greenhouse (described in the plant preparation section). To maintain the soil moisture $(70 \%)$ at field capacity, the soils were watered with As/Cd-free tap water. Then, the soil samples were collected and incubated for $5 \mathrm{~d}, 30 \mathrm{~d}$, and $90 \mathrm{~d}$. The soil $\mathrm{pH}$ and available As/Cd as well as residual As/Cd were analysis.

Pot experiment 2: To study the accumulation of $\mathrm{As}$ and $\mathrm{Cd}$ in cabbages planted in the soil (soil 2), the soils were treated with $\mathrm{Fe}_{2} \mathrm{O}_{3}, \mathrm{BC}$, and FMB. Based on the results of pot experiment 1 , we selected $0.5 \%$ as the experimental concentration. After 10 days of cultivation, the seedlings were transferred into $22-\mathrm{cm}$-diameter round plastic pots $(5 \mathrm{~kg}$ soil). Each treatment had three replications, and the seedlings were in similar sizes. One group was replicated for three times as a control group without any soil amendment supplement. In total, there were 12 pots in the greenhouse (described in the plant preparation section). To maintain $50 \%$ soil moisture, the plants were sprayed with tap water daily. The plants were harvested after $30 \mathrm{~d}$ of cultivation. We determined the flesh weight (FW), dry weight (DW), and the contents of total $\mathrm{Cd}$ and total As.

\section{Chemical analysis of soil and plant samples}

All the chemicals were reagent grade in this study. The soil $\mathrm{pH}$, ammonium $\mathrm{N}$, available $\mathrm{P}$, and available $\mathrm{K}$ of soil 1 and soil 2 were determined by using routine analytical methods (Liu et al., 2018). Soil samples (about $0.25 \mathrm{~g}$ ) were digested with 12 $\mathrm{mL}$ of $\mathrm{HCl}: \mathrm{HNO}_{3}(4: 1, v / v)$. The concentration of pseudo-total $\mathrm{Cd}$ was measured by using the atomic absorption spectrophotometry method (ICP, PE-AA700, USA). Soil pseudo-total (Aqua regia) As was determined by hydride generation-atomic fluorescence (SA-20). The concentrations of soil available $\mathrm{Cd}$ and available As were extracted with $0.005 \mathrm{M}$ DTPA $+0.01 \mathrm{M} \mathrm{CaCl}_{2}+0.1 \mathrm{M}$ TEA) and $0.5 \mathrm{M} \mathrm{NaHCO}_{3}(\mathrm{pH}$ $8.5)+0.5 \mathrm{M}\left(\mathrm{NaH}_{2} \mathrm{PO}_{4}\right)+0.1 \mathrm{M} \mathrm{HCl}$, respectively. The soil homogenate of $\mathrm{Cd}$ was shaken at $5000 \times g$ for $20 \mathrm{~min}$, and then the supernatant was tested by ICP-OES (PEAA700). The suspension of As was shaken at $250 \times g$ for $1 \mathrm{~h}$, and then the supernatant was determined by hydride generation atomic fluorescence spectrometry (HG-AFS, SA20, China).

The measured soil properties of soil 1 and soil 2 are summarized in Table 1. We extracted soil residual As and soil residual $\mathrm{Cd}$ in pot experiment 1 according to the fivestep sequential extraction scheme based on the procedures described by Wenzel et al. (2001) and Tessier et al. (1979). Then we determined the residual As and residual Cd by HG-AFS (SA-20) and ICP-OES (PE-AA700), respectively. The measurement methods of the other soil properties in pot experiment 1 and experiment 2 were the same as in soil 1 and soil 2.

The harvested plants were washed with water. The moisture on the plant surface was absorbed by paper, and then we determined the fresh weight $(\mathrm{FW})$. The plants were separated into roots, stems, and leaves and then dried $\left(65^{\circ} \mathrm{C}\right)$ until a constant weight to determine the dry weight (DW). The dry shoots were digested with a mixture of $\mathrm{HNO}_{3}$ and $\mathrm{HClO}_{4}(9: 1, v / v)$. We determined the Cd concentration by ICP-OES. The dry shoot was digested with $\mathrm{HClO}_{4}: \mathrm{H}_{2} \mathrm{SO}_{4}: \mathrm{HNO}_{3}\left(1: 1.5: 4\right.$, v/v) at $110-130{ }^{\circ} \mathrm{C}$ (Qiao et al., 2018a). We measured the total As concentration by HG-AFS (SA-20). To ensure quality control, certified standard reference materials were addressed (soil $\mathrm{Cd}$ : GBW(E)07429, plant Cd: GBW(E)10023; soil As: GBW(E)070008, plant As: GBW(E)10014). 
Table 1. The physicochemical properties of the tested soil

\begin{tabular}{|c|c|c|c|c|c|c|c|c|}
\hline & $\mathbf{p H}$ & $\begin{array}{c}\text { Ammonium } \\
\text { nitrogen } \\
\left(\mathbf{m g}^{\circ} \mathbf{k g}^{-1}\right)\end{array}$ & $\underset{\left(\mathbf{m g} \cdot \mathbf{k g}^{-1}\right)}{\text { Available P }}$ & $\begin{array}{c}\text { Available K } \\
\left(\mathbf{m g}^{\prime} \mathbf{k g}^{-1}\right)\end{array}$ & $\begin{array}{l}\text { Total Cd } \\
\left(\mathbf{m g}^{-} \mathbf{k g}^{-1}\right)\end{array}$ & $\begin{array}{c}\text { Total As } \\
\left(\mathbf{m g} \cdot \mathbf{k g}^{-1}\right)\end{array}$ & $\begin{array}{c}\text { Available } \\
\text { Cd }\left(\mathrm{mg}^{\circ} \mathrm{kg}^{-1}\right)\end{array}$ & $\begin{array}{c}\text { Available As } \\
\left(\mathbf{m g} \cdot \mathbf{k g}^{-1}\right)\end{array}$ \\
\hline Soil 1 & 6.46 & 12.4 & 8.53 & 3.10 & 19.54 & 332.91 & 5.41 & 9.2 \\
\hline Soil 2 & 5.62 & 27.3 & 17.4 & 13.5 & 5.19 & 133.54 & 1.23 & 0.77 \\
\hline
\end{tabular}

\section{Statistical analyses}

The mean and standard deviation (SD) of the experimental data were analyzed in Microsoft Office Excel 2010 (Microsoft Corporation, Redmond, WA, USA). Two-way analysis of variances (ANONA) were performed with SPSS 18.0 software (IBM Corporation, Armonk, USA). Duncan's multiple range tests as a multiple compassion procedure at significant levels of $P<0.05$. Figures were plotted using Origin 2020b (OriginLab, Northampton, Massachusetts, USA).

\section{Results}

\section{Characterization of biochar and Fe-modified biochar}

XRD was used to characterize the crystalline structure of the BC and FMB. As shown in Figure 1, magnetite, hematite, and carbon were presented on the surfaces of the FMB. Only one carbon was on the surface of the BC. The location and intensity of the XRD peaks in the FMB matched the two reference peaks. The peaks at $2 \theta$ of $30.09^{\circ}$, $35.44^{\circ}, 43.07^{\circ}, 56.96^{\circ}$, and $62.54^{\circ}$ corresponded to $\mathrm{Fe}_{3} \mathrm{O}_{4}$ (reference code 01-0893854 ), and the peaks at $2 \theta$ of $24.13^{\circ}, 33.14^{\circ}, 35.63^{\circ}, 49.52^{\circ}, 54.06^{\circ}, 57.66^{\circ}$, and $62.42^{\circ}$ were identified as $\mathrm{Fe}_{2} \mathrm{O}_{3}$ (reference code 01-079-1741), respectively. The peaks of biochar at $2 \theta$ of $23.36^{\circ}$ and $43.33^{\circ}$ belonged to amorphous carbon.

The SEM results showed that there was a hierarchical porous framework in the bamboo woods of the biochar (Fig. 2). The diameters of the parenchyma cells and fibres were about $10-40 \mu \mathrm{m}$ and $<1 \mu \mathrm{m}$, respectively. The surfaces of the FMB were filled with particles, even in the pores. To determine the ingredients of the particles on the surfaces of the FMB, we performed an EDS analysis. The results illustrated that the Fe ion was associated with the FMB surface (Fig. 3).

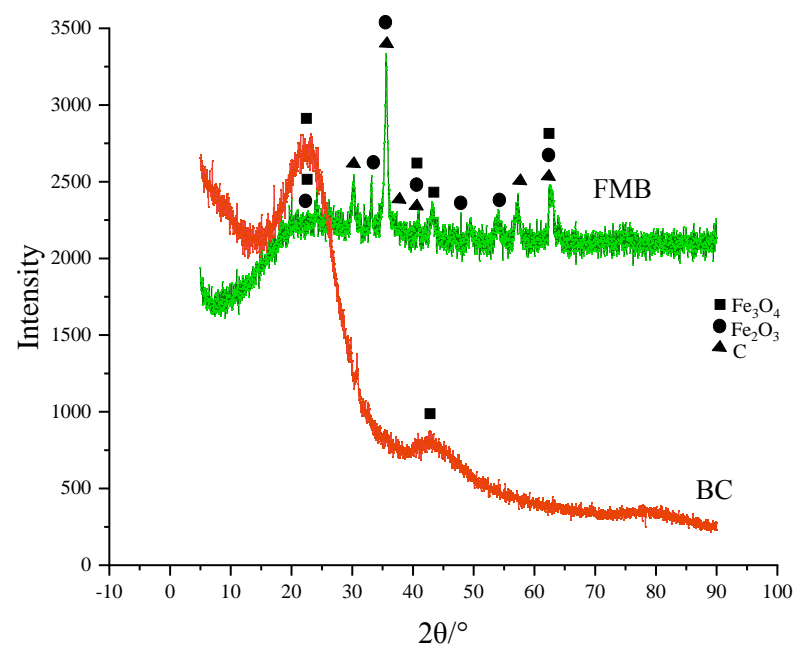

Figure 1. XRD patterns of the $B C$ and FMB 


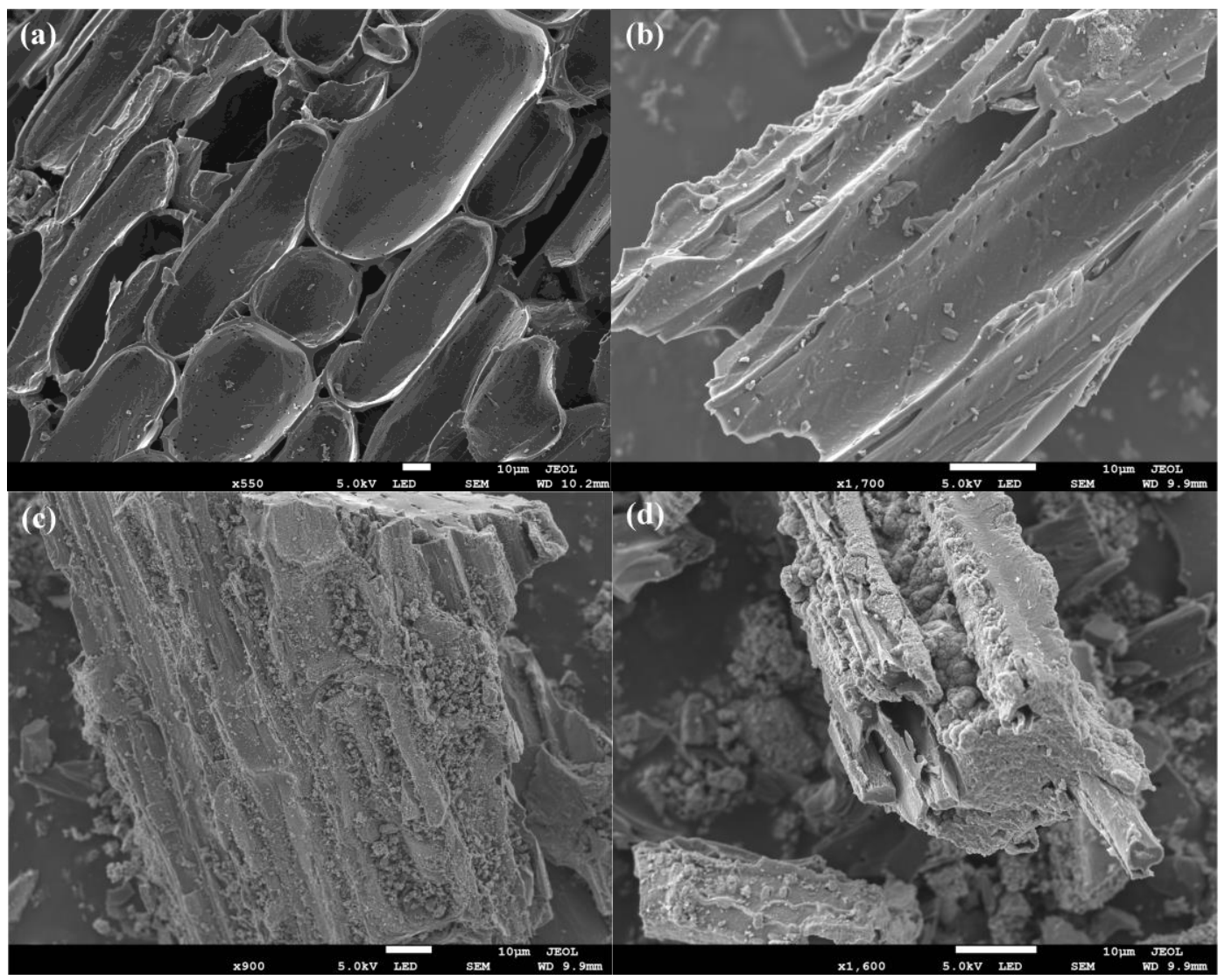

Figure 2. SEM images of BC and FMB: $(a, b)$ SEM images of $B C$, and $(c, d)$ SEM images of $F M B$
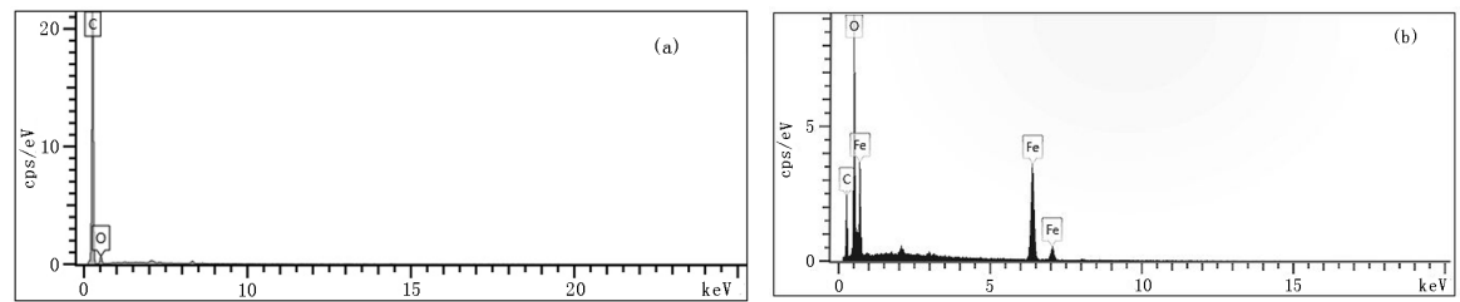

Figure 3. EDS spectrum of $B C$ and FMB: ( $a$ was the $B C$ and $b$ was the FMB)

\section{Electrochemical detection of $B C$ and $F M B$}

We used the CV patterns in this study to analyze the electro-oxidation mechanism of the biochar and FMB. There were no oxidation peaks and reduction peaks in the CV of the BC (Fig. 4) at 100, 300, and $500 \mathrm{mV}$. The $\mathrm{CV}$ pattern of the FMB presented redox and oxidation peaks. Furthermore, the peak was more obvious at $500 \mathrm{mV}$ than at 100 and $300 \mathrm{mV}$. The redox peak and oxidation peak were positioned at $-0.63 \mathrm{~V}$ and -1.11 $\mathrm{V}$, respectively. The EIS of the BC and FMB showed a semicircle line and an almost straight line in the high- and low-frequency range, respectively (Fig. 5). The EIS of $\mathrm{Fe}_{2} \mathrm{O}_{3}$, however, presented a line in all frequency ranges. In the high-frequency range, the data fitted from the semicircle indicated that the FMB electrode had a lower CD resistance of $15000 \Omega$ than the $\mathrm{BC}$. 


$$
-4771-
$$
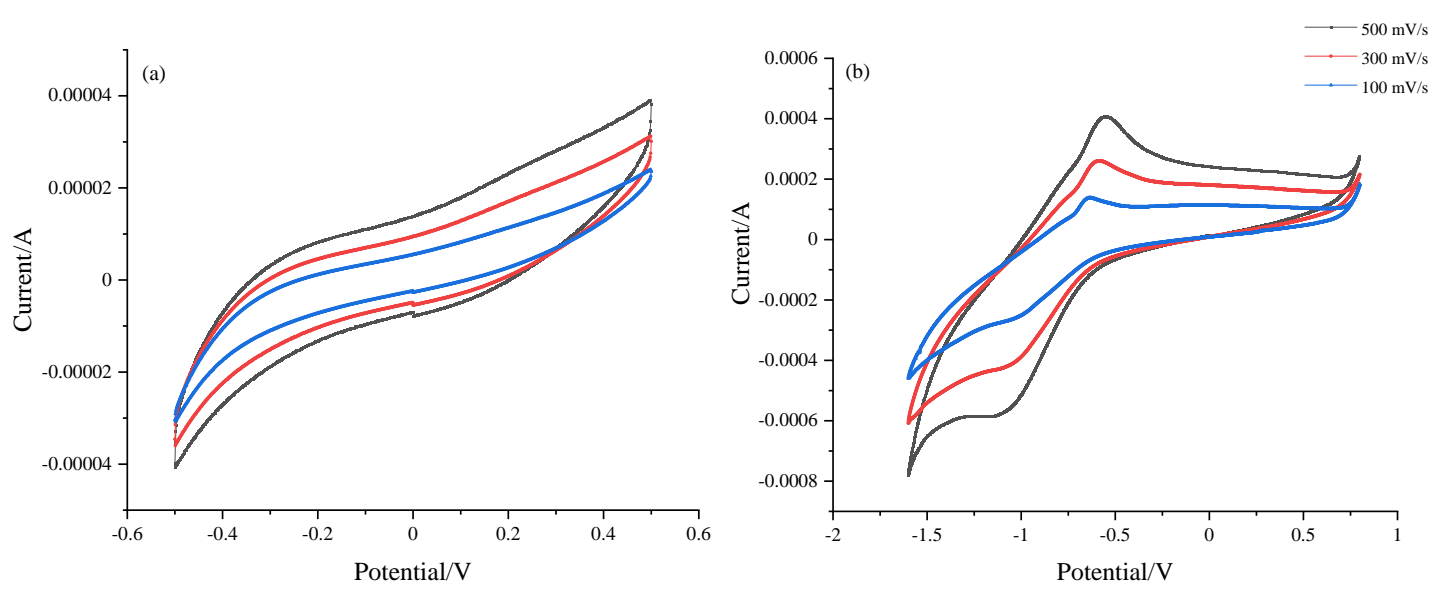

Figure 4. Cyclic voltammeter curves after BC and FMB addition
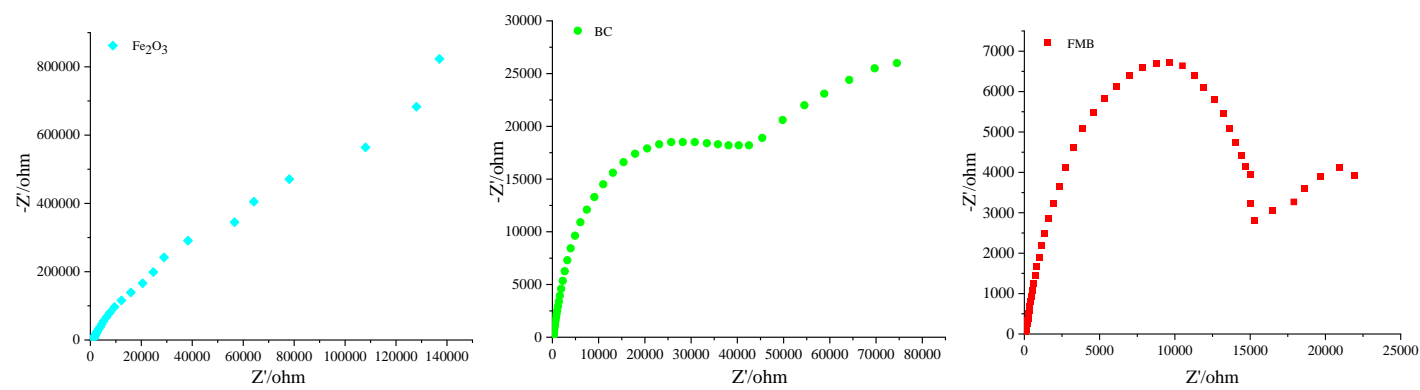

Figure 5. EIS patterns of the electrodes in the different treatments

\section{Soil-column experiment at different treatment times}

The result of soil-column experiment showed that the $\mathrm{pH}$ of the $\mathrm{Fe}_{2} \mathrm{O}_{3}$ treatment was not significantly different from the control at the different treatment concentrations (Table 2). On the fifth day, the $\mathrm{pH}$ of the $\mathrm{BC}$ and $\mathrm{FMB}$ was significantly higher than the control at three addition concentrations. The $\mathrm{pH}$ reached the maximum in the two materials at a concentration of $1 \%$, namely, $6.63 \pm 0.01$ (BC) and $6.70 \pm 0.03$ (FMB). On the 90th day, the $\mathrm{pH}$ in the three treatment concentrations of $\mathrm{Fe}_{2} \mathrm{O}_{3}$ was higher than that in the control group. There was no significant difference between the three $\mathrm{BC}$ treatment concentrations, but they were all higher than the control. The addition of different concentrations of FMB had enhanced the $\mathrm{pH}$ in comparison to the control group.

The concentrations of available As and available $\mathrm{Cd}$ in the soil-column experiment were determined on the fifth, 30th, and 90th days, respectively. The data were presented using the ratio of the experimental group and the control group (Fig. 6). As shown in Figure 6, the ratios of As reached the lowest values on the 30th day in the different material treatments. In particular, the As ratio in the BC and FMB on the 30th day was significantly lower than under the other treatment durations. The As ratio decreased with increased concentrations of $\mathrm{Fe}_{2} \mathrm{O}_{3}$ and $\mathrm{FMB}$, whereas the addition of $\mathrm{BC}$ showed the opposite trend. When the concentration was $0.2 \%$, the As ratios in the $\mathrm{Fe}_{2} \mathrm{O}_{3}, \mathrm{BC}$, and FMB were $78 \%, 44 \%$, and $50 \%$, respectively. When the addition concentration was $0.5 \%$, the corresponding values were $75 \%, 49 \%$, and $46 \%$, respectively. The addition of $\mathrm{Fe}_{2} \mathrm{O}_{3}$ and FMB had the lowest values at a concentration of $1 \%$, which were $62 \%$ and 
$44 \%$, respectively. The As ratio was $53 \%$ with $1 \%$ BC addition. The results illustrated that $0.5 \%$ and $1 \%$ concentrations had no significantly different effects on the As ratio, except under $\mathrm{Fe}_{2} \mathrm{O}_{3}$ addition. On the fifth day, the three materials showed differing trends with increased concentration addition. The lowest As ratios of $\mathrm{Fe}_{2} \mathrm{O}_{3}, \mathrm{BC}$, and FMB were $76 \%, 75 \%$, and $68 \%$, respectively. On the 90th day, the trends in $\mathrm{Fe}_{2} \mathrm{O}_{3}, \mathrm{BC}$, and FMB were similar to those on the 30th day. The lowest As ratios in the $\mathrm{Fe}_{2} \mathrm{O}_{3}, \mathrm{BC}$, and FMB treatments were $72 \%, 75 \%$, and $60 \%$, respectively.

Table 2. Soil $p H$ at different treatment durations

\begin{tabular}{c|c|c|c|c}
\hline Time/d & $\begin{array}{c}\text { Addition } \\
\text { concentration }\end{array}$ & $\mathbf{F e}_{2} \mathbf{O}_{3}$ & $\mathbf{B C}$ & FMB \\
\hline \multirow{3}{*}{5} & $0 \%$ & $6.46 \pm 0.05 \mathrm{a}$ & $6.46 \pm 0.05 \mathrm{~d}$ & $6.46 \pm 0.05 \mathrm{c}$ \\
& $0.2 \%$ & $6.60 \pm 0.04 \mathrm{a}$ & $6.60 \pm 0.01 \mathrm{~b}$ & $6.61 \pm 0.01 \mathrm{~b}$ \\
& $0.5 \%$ & $6.73 \pm 0.01 \mathrm{a}$ & $6.54 \pm 0.03 \mathrm{c}$ & $6.61 \pm 0.02 \mathrm{~b}$ \\
& $1 \%$ & $6.50 \pm 0.01 \mathrm{a}$ & $6.63 \pm 0.01 \mathrm{a}$ & $6.70 \pm 0.03 \mathrm{a}$ \\
\hline \multirow{3}{*}{30} & $0 \%$ & $6.46 \pm 0.05 \mathrm{a}$ & $6.46 \pm 0.05 \mathrm{a}$ & $6.46 \pm 0.05 \mathrm{a}$ \\
& $0.2 \%$ & $6.51 \pm 0.12 \mathrm{a}$ & $6.47 \pm 0.03 \mathrm{a}$ & $6.50 \pm 0.06 \mathrm{a}$ \\
& $0.5 \%$ & $6.48 \pm 0.03 \mathrm{a}$ & $6.53 \pm 0.10 \mathrm{a}$ & $6.51 \pm 0.06 \mathrm{a}$ \\
& $1 \%$ & $6.56 \pm 0.22 \mathrm{a}$ & $6.53 \pm 0.04 \mathrm{a}$ & $6.54 \pm 0.04 \mathrm{a}$ \\
\hline \multirow{3}{*}{90} & $0 \%$ & $6.46 \pm 0.05 \mathrm{c}$ & $6.46 \pm 0.05 \mathrm{~b}$ & $6.46 \pm 0.05 \mathrm{c}$ \\
& $0.2 \%$ & $6.60 \pm 0.07 \mathrm{bc}$ & $6.69 \pm 0.08 \mathrm{a}$ & $6.76 \pm 0.10 \mathrm{a}$ \\
& $0.5 \%$ & $6.65 \pm 0.05 \mathrm{ab}$ & $6.70 \pm 0.10 \mathrm{a}$ & $6.72 \pm 0.12 \mathrm{a}$ \\
& $1 \%$ & $6.68 \pm 0.03 \mathrm{a}$ & $6.63 \pm 0.03 \mathrm{a}$ & $6.68 \pm 0.02 \mathrm{~b}$ \\
\hline
\end{tabular}

Results are means $\pm \mathrm{SD}(\mathrm{n}=3)$. Means within the same column are not significantly different according to the LSD test $(\mathrm{p}<0.05)$
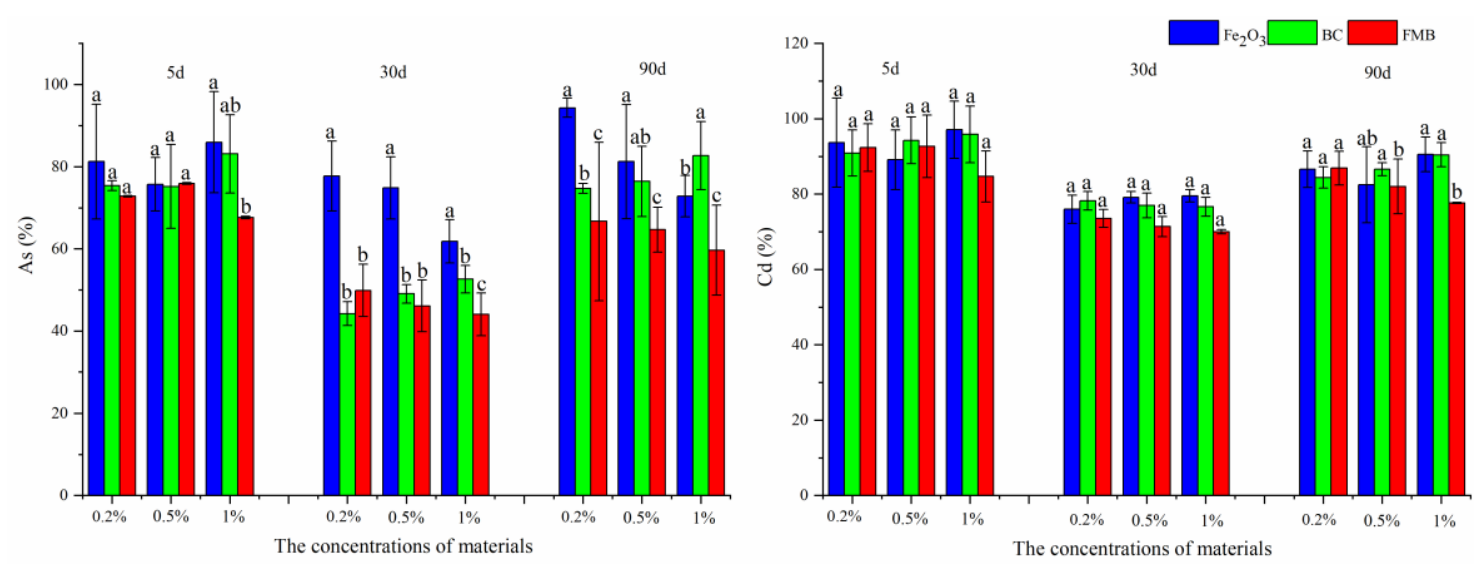

Figure 6. Reduction rates of available Cd/As in the different treatments

The $\mathrm{Cd}$ ratios of $\mathrm{Fe}_{2} \mathrm{O}_{3}, \mathrm{BC}$, and $\mathrm{FMB}$ on the 30th day were all lower than the other treatment durations at different concentrations (Fig. 6). The trends in $\mathrm{Cd}$ ratios in the biochar and FMB were similar and decreased with increased concentration. The addition of $\mathrm{Fe}_{2} \mathrm{O}_{3}$, however, showed the opposite trend. The lowest $\mathrm{Cd}$ ratio in the FMB was at a concentration of $1 \%(70 \%)$. It was only slightly lower than the concentration of $0.5 \%(71 \%)$. Under $0.5 \%$ and $1 \%$ addition, the $\mathrm{BC}$ had the same Cd ratio $(77 \%)$, which was lower than under $0.2 \%$ addition. The addition of $\mathrm{Fe}_{2} \mathrm{O}_{3}$ had the lowest $\mathrm{Cd}$ ratio $(76 \%)$ at a concentration of $0.2 \%$, which was slightly higher than the concentration of 
$0.5 \%(79 \%)$. On the fifth day, the lowest $\mathrm{Cd}$ ratios in the $\mathrm{Fe}_{2} \mathrm{O}_{3}, \mathrm{BC}$, and $\mathrm{FMB}$ treatments were $89 \%, 91 \%$, and $85 \%$, respectively. On the 90th day, the corresponding values were $82 \%, 84 \%$, and $82 \%$, respectively.

\section{Chemical forms of soil As and Cd after harvesting}

Based on the results of the soil-column experiment, the concentrations of soil available As and available Cd exhibited the lowest values on the thirtieth day. When the treatment concentration was $1 \%$, the BC and FMB had lower available As and available $\mathrm{Cd}$ concentrations compared with the other two concentrations. $\mathrm{Fe}_{2} \mathrm{O}_{3}$ had the lowest available $\mathrm{As}$ and available $\mathrm{Cd}$ concentrations at a concentration of $0.2 \%$. However, three soil amendments all had better treatment effects on the soil $\mathrm{Cd}$ and As when the addition concentration was $0.5 \%$. Therefore, we selected a concentration of $0.5 \%$ for further experiments according to the economy and efficiency.

Soil available As concentrations in the $\mathrm{Fe}_{2} \mathrm{O}_{3}, \mathrm{BC}$, and $\mathrm{FMB}$ treatments differed significantly (Fig. 7). The soil available As concentration in the $\mathrm{BC}$ treatment $\left(0.92 \pm 0.17 \mathrm{mg} \cdot \mathrm{kg}^{-1}\right)$ was higher than in the control group $\left(0.81 \pm 0.04 \mathrm{mg} \cdot \mathrm{kg}^{-1}\right)$. Conversely, the concentration in the FMB treatment $\left(0.71 \pm 0.01 \mathrm{mg} \cdot \mathrm{kg}^{-1}\right)$ was lower than in the control group. The addition of $\mathrm{Fe}_{2} \mathrm{O}_{3}$ resulted in the highest available $\mathrm{Cd}$ concentration $\left(1.39 \pm 0.16 \mathrm{mg} \cdot \mathrm{kg}^{-1}\right)$, followed by BC and FMB at $1.19 \pm 0.07 \mathrm{mg} \bullet \mathrm{kg}^{-1}$ and $1.16 \pm 0.08 \mathrm{mg} \cdot \mathrm{kg}^{-1}$, respectively.
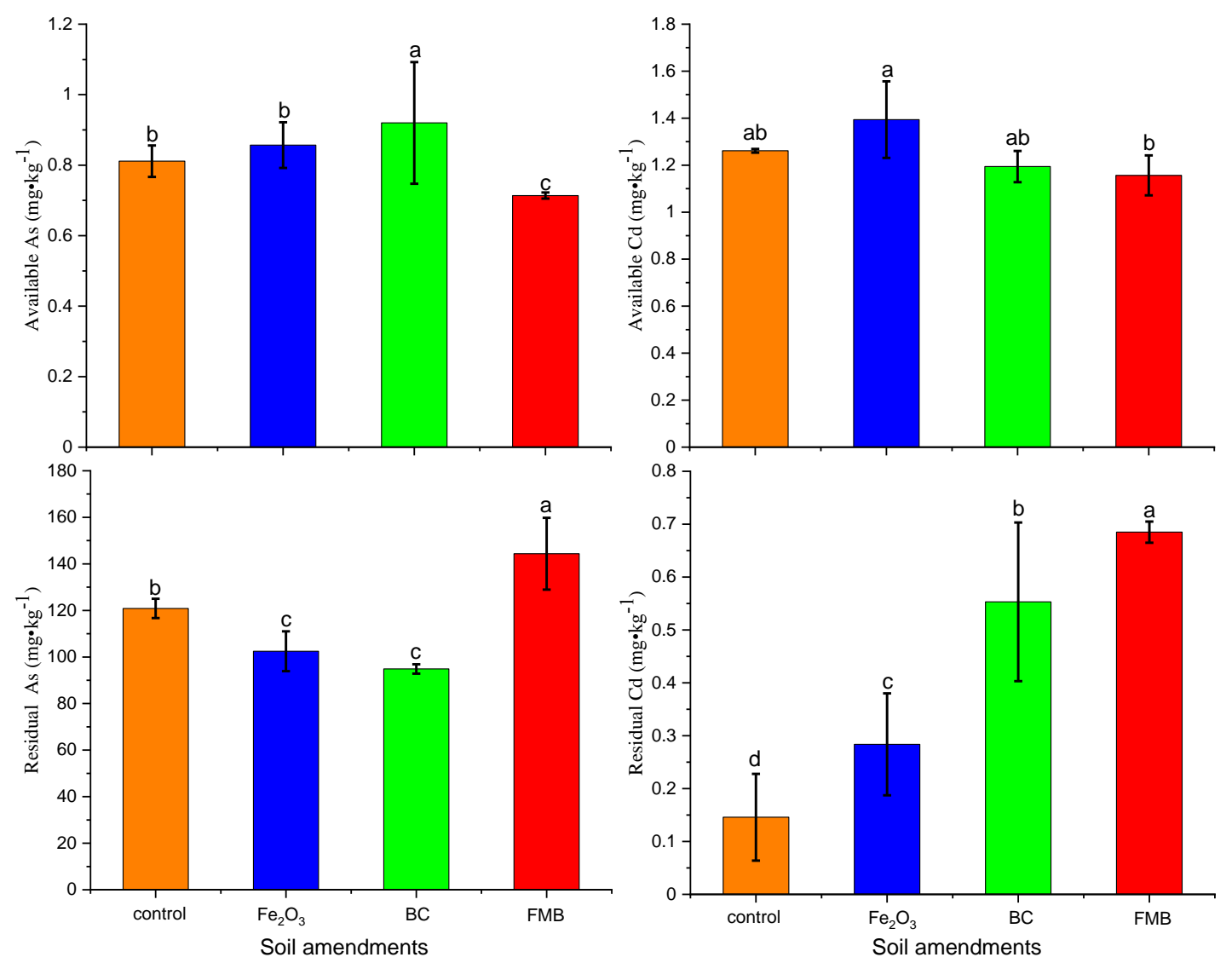

Figure 7. The chemical format of Cd/As after harvesting. Results are means $\pm S D(n=3)$. Means within the same column are not significantly different according to the LSD test $(p<0.05)$ 
Supplementation with FMB significantly increased the residual As concentration compared with the control group (Fig. 7). The addition of $\mathrm{Fe}_{2} \mathrm{O}_{3}$ and $\mathrm{BC}$, however, presented an opposite trend. The concentrations of residual As in $\mathrm{Fe}_{2} \mathrm{O}_{3}$ and $\mathrm{BC}$ were $102 \pm 8.56 \mathrm{mg} \bullet \mathrm{kg}^{-1}$ and $94.9 \pm 2.00 \mathrm{mg} \bullet \mathrm{kg}^{-1}$, respectively, which were lower than in the control group. The residual $\mathrm{Cd}$ concentrations in the three materials were significantly increased in comparison to the control group. The concentrations of residual $\mathrm{Cd}$ in the control, $\mathrm{Fe}_{2} \mathrm{O}_{3}, \mathrm{BC}$, and FMB were $0.15 \pm 0.08 \mathrm{mg} \cdot \mathrm{kg}^{-1}, 0.28 \pm 0.10 \mathrm{mg} \cdot \mathrm{kg}^{-1}$, $0.55 \pm 0.15 \mathrm{mg} \bullet \mathrm{kg}^{-1}$, and $0.68 \pm 0.02 \mathrm{mg} \bullet \mathrm{kg}^{-1}$, respectively.

\section{Cabbage biomass and As/Cd accumulation under the different treatments}

$\mathrm{BC}$ and FMB increased the FW of cabbages compared to control and $\mathrm{Fe}_{2} \mathrm{O}_{3}$ (Fig. 8). The FW in the soil under BC addition had the highest value of $17.5 \pm 0.85 \mathrm{mg} \cdot \mathrm{kg}^{-1}$, followed by FMB $\left(15.2 \pm 1.58 \mathrm{mg} \bullet \mathrm{kg}^{-1}\right)$ and $\mathrm{Fe}_{2} \mathrm{O}_{3}\left(13.3 \pm 1.15 \mathrm{mg} \cdot \mathrm{kg}^{-1}\right)$. Compared with the control group, the addition of different materials had no significant impact on the DW of the cabbages. The DWs of the cabbages in the control, $\mathrm{Fe}_{2} \mathrm{O}_{3}, \mathrm{BC}$ and FMB treatments were $0.27 \pm 0.01 \mathrm{mg} \bullet \mathrm{kg}^{-1}, 0.24 \pm 0.04 \mathrm{mg} \bullet \mathrm{kg}^{-1}, 0.30 \pm 0.08 \mathrm{mg} \bullet \mathrm{kg}^{-1}$ and $0.24 \pm 0.03 \mathrm{mg} \bullet \mathrm{kg}^{-1}$, respectively.
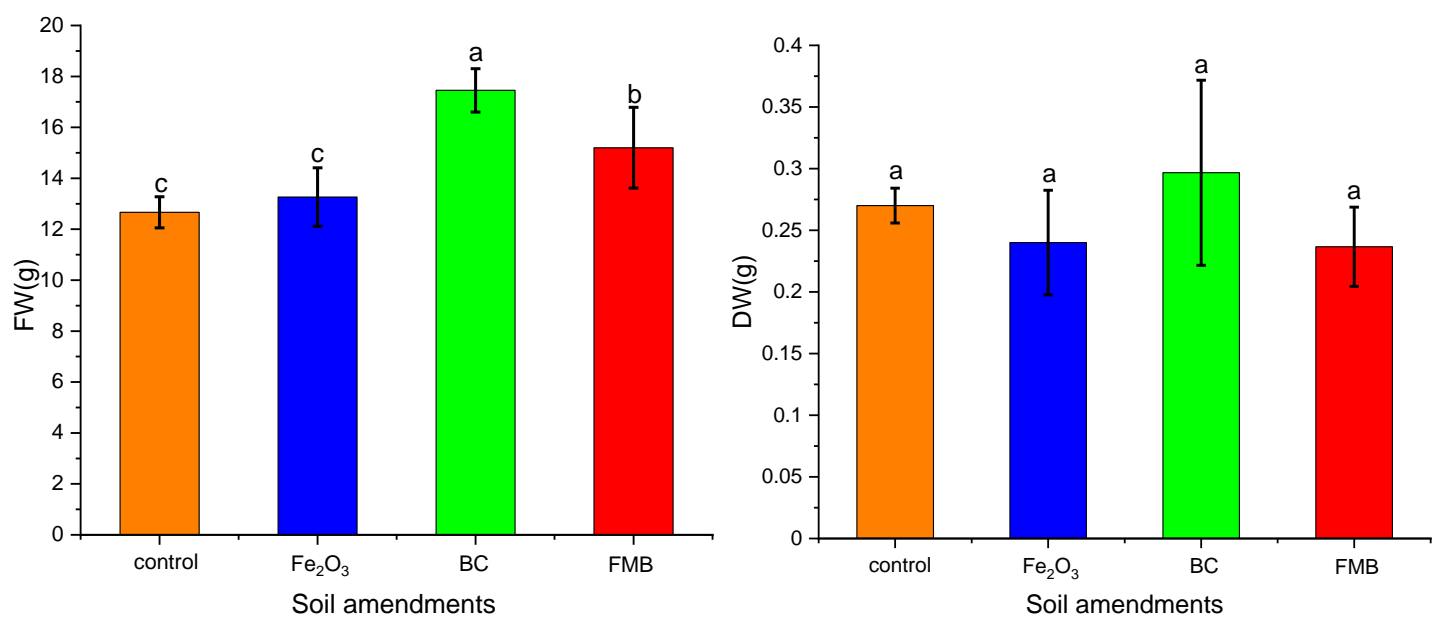

Figure 8. Cabbage biomass of the different treatments. Results are means $\pm S D(n=3)$. Means within the same column are not significantly different according to the LSD test $(p<0.05)$

The As concentrations of the cabbages were significantly lower than in the control group under treatment with the different materials (Fig. 9), being $3.14 \pm 0.33 \mathrm{mg}^{\circ} \mathrm{kg}^{-1}$, $2.87 \pm 0.33 \mathrm{mg} \bullet \mathrm{kg}^{-1}, 2.15 \pm 0.20 \mathrm{mg} \bullet \mathrm{kg}^{-1}$, and $2.28 \pm 0.19 \mathrm{mg} \bullet \mathrm{kg}^{-1}$ in the control, $\mathrm{Fe}_{2} \mathrm{O}_{3}$, $\mathrm{BC}$, and FMB treatments, respectively. The $\mathrm{Cd}$ concentrations of the cabbages presented different trends as As. Only FMB significantly reduced the Cd concentrations in the cabbages. The $\mathrm{Cd}$ concentrations of the cabbages in the control, $\mathrm{Fe}_{2} \mathrm{O}_{3}, \mathrm{BC}$, and FMB treatments were $15.9 \pm 0.11 \mathrm{mg} \bullet \mathrm{kg}-1,14.6 \pm 0.77 \mathrm{mg} \bullet \mathrm{kg}^{-1}, 13.7 \pm 3.67 \mathrm{mg} \cdot \mathrm{kg}^{-1}$, and $11.1 \pm 1.23 \mathrm{mg} \cdot \mathrm{kg}^{-1}$, respectively.

\section{Discussion}

The total concentrations of $\mathrm{Cd}$ in the cabbages decreased under the three soil amendment treatments compared with the control group (Fig. 9). BC increased the 
residual $\mathrm{Cd}$ concentration, indicating that $\mathrm{BC}$ may have the ability to reduce the $\mathrm{Cd}$ mobility in the soil. Some studies indicated that the immobilization of $\mathrm{Cd}$ by biochar may be related to specific adsorption, which specifically occurs with organic matter (Zhang et al., 2020). The soil Cd was immobilized by forming ionic, covalent, or hydrogen bonds on the surface of the biochar (Bian et al., 2014). Compared with the $\mathrm{BC}$, the FMB was better at reducing the soil Cd mobility (Fig. 7) and $\mathrm{Cd}$ accumulation in cabbages (Fig. 9). The FMB had the ability to adsorb $\mathrm{Cd}$ on its surface to form unlabile chemical forms, thus reducing the mobility of $\mathrm{Cd}$. In addition, it indicated that the Fe could reduce the Cd uptake by plants. The rice cultured in Fe-deficient medium absorbed more Cd than rice cultured in Fe-sufficient medium (Nakanishi et al., 2006). Therefore, $\mathrm{Cd}$ and $\mathrm{Fe}$ may have the same uptake pathway in the plant. Supplementation with $\mathrm{Fe}$ could reduce the Cd uptake into the cabbage, as they may be in competition for the same heavy metal transporters. Yin et al. (2017) reported that Fe ions could inhibit the uptake and accumulation of $\mathrm{Cd}$ in plants. Therefore, FMB has the advantages of both biochar and $\mathrm{Fe}$ oxides, and it can promote the stabilization of soil $\mathrm{Cd}$ and thus reduce $\mathrm{Cd}$ accumulation in the cabbages.
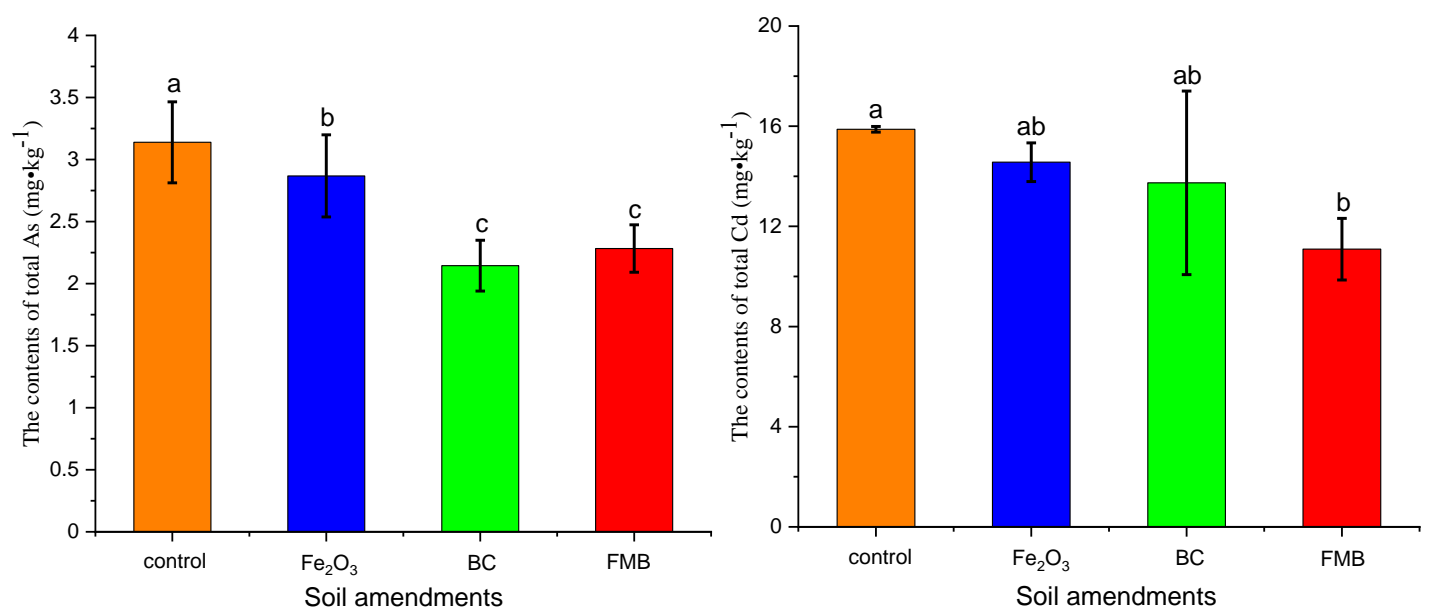

Figure 9. Total content of Cd/As in cabbage. Results are means $\pm S D(n=3)$. Means within the same column are not significantly different according to the LSD test $(p<0.05)$

FMB significantly decreased the soil As mobility (Fig. 7) and its accumulation in the cabbage (Fig. 9). Arsenic has been shown to have a high affinity for iron oxide surfaces (Wen et al., 2020). As and $\mathrm{Fe}$ can form the amorphous iron (III) arsenate ( $\mathrm{FeAsO} \cdot \mathrm{H}_{4} \mathrm{O}$ ) and scorodite $\left(\mathrm{FeAsO}_{4} \cdot 2 \mathrm{H}_{2} \mathrm{O}\right)$ to influence As immobilization and bioavailability in the soil (Mladenov et al., 2010; Pedersen et al., 2006). The surface of the FMB was covered with $\mathrm{Fe}_{2} \mathrm{O}_{3}$ and $\mathrm{Fe}_{3} \mathrm{O}_{4}$ (Figs. 1-3). Fe oxides such as goethite, hematite, and lepidocrocite are related to soil chemical stabilization, especially As stability. The adsorption of As by natural iron oxides (hematite, magnetite, and goethite) can be fitted with a noncompetitive Langmuir isotherm (Mladenov et al., 2010). In addition, previous studies showed that $\mathrm{Fe}$ contents of iron plaques increased with the addition of $\mathrm{Fe}$ compound in the soil and thus limited the As uptake into the plant roots (Wen et al., 2020; Irshad et al., 2020; Yin et al., 2017). Therefore, FMB reduced the accumulation of $\mathrm{As}$ in the cabbages by reducing the As uptake. $\mathrm{Fe}_{2} \mathrm{O}_{3}$ reduced the total As accumulation in the cabbage compared with the control group (Fig. 9), but the 
accumulation of As in the cabbages was significantly higher than in the BC and FMB treatments. The $\mathrm{Cd}$ accumulation in the cabbage showed the same trend as As. This indicated that $\mathrm{Fe}_{2} \mathrm{O}_{3}$ is not suitable for the treatment of $\mathrm{As} / \mathrm{Cd}$-contaminated soil. $\mathrm{BC}$ could promote the mobility of As in the soil (Fig. 7). This was proved by the results of Beesley et al. (2013), Wu et al. (2015) and Yin et al. (2017), they found that biochar increased the As desorption from the soil solid phased by ligand exchange. The transfer electrons of BC and FMB may be another important factor, as they influence the As bioavailability in the environment. Biochar contains a variety of functional groups, such as quinones, furans, and phenols, giving it the ability to store and transfer electrons. Qiao et al. (2018b) discovered that biochar at the cell surface of Fe(III)-/As(V)-reducing bacteria could serve as electron shuttles between the outer-membrane reductases from dissimilatory $\mathrm{Fe}(\mathrm{III})-/ \mathrm{As}(\mathrm{V})$-reducing bacteria and the terminal electron acceptor $\mathrm{Fe}(\mathrm{III}) / \mathrm{As}(\mathrm{V})$. There are two steps between metal-reducing bacteria and As (V) when biochar serves as the electron shuttle: biochar reduction by the $\mathrm{Fe}(\mathrm{III}) / \mathrm{As}$ (V)-reducing bacteria, followed by the reduction of abiotic As (V) by the microbial reduced biochar (Qiao et al., 2018b). Therefore, biochar facilitates the release of As (V) into the soil. The CVs of the BC showed no obvious current peaks (Fig. 4) and were similar to natural organic matter. This indicated that the BC in this study had the slow electron transfer and low reduction potentials of redox-active moieties (Sun et al., 2017). Ryu et al. (2015) found no obvious redox peaks in the CV curves of biochar. FMB had an oxidation peak and reduction peak in the CV curves (Fig. 4), which indicated that the FMB had higher electron transfer ability than the BC. The result of EIS also showed that the FMB had better electrolyte infiltration and charge-transport capability than biochar (Fig. 5). In addition, the electron transfer from Fe (II) to goethite formed a reactive $\mathrm{Fe}$ (III) species as a reactive intermediate phase, which could interact with As (III) by ternary complex formation, leading to As (III) oxidation (Amstaetter et al., 2010). The toxicity and mobility of As (V) species were less than those of As (III) in the soil (Xu et al., 2017), and the As (V) tended was more easily adsorbed by Fe-oxides (Wu et al., 2018). Therefore, the FMB could promote the oxidation of As (III) to As (V) by electron transfer and then reduce the As mobility in the soil. This is one of the main mechanisms by which FMB has a better effect on stabilizing soil As than BC. However, the total As content in the cabbage was reduced by the BC addition compared with the control group (Fig. 9). This may have been influenced by As soil-plant transfer coefficients. In Kloke et al. (1984), the As soil-plant transfer coefficients ranged between 0.01 and 0.1 , whereas the results of Warren et al. (2003) reported that the transfer coefficients ranged between 0.0007 and 0.032 . The transfer coefficient is influenced by soil texture. The content of sand in the soil increases the transfer coefficient, whereas the content of clay decreases the transfer coefficient (Warren et al., 2003). Therefore, the uptake of As is relatively higher in sands and sandy loams than in clays. In this study, the soil collected from the farmlands was mainly composed of clay, and thus the As transfer coefficient of the soil to plant was lower. This may be the main reason for the low As accumulation in the cabbages under BC addition.

Excepting the obvious effect of FMB in reducing the As and $\mathrm{Cd}$ accumulation in cabbage in comparison to $\mathrm{BC}$ and $\mathrm{Fe}_{2} \mathrm{O}_{3}$, we did not find a significant difference in the dry weight of the cabbages among the three amendments (Fig. 8). BC and FMB significantly increased the fresh weight of the cabbages. Dong et al. (2016) found that when the addition concentration of biochar was $20 \mathrm{~g} / \mathrm{kg}$, it could significantly enhance the biomass of cabbage. Biochar is rich in organic matter and nutrients $(\mathrm{N}, \mathrm{P}$, and $\mathrm{K}$ ), 
which could increase the contents of organic matter, available $\mathrm{N}$, available $\mathrm{P}$, and available $\mathrm{K}$ in the soil, thus promoting cabbage growth (Glaser et al., 2002). The effects of biochar on cabbage growth, however, are influenced by the soil physical and chemical properties. Thus, the effects of biochar on the biomass of plants may present different trends. Park et al. (2011) discovered that biochar would not increase the dry weight of plants. Fe oxides could alter the physiological functions of plants and cause iron poisoning, thus reducing the plant biomass (Xiao et al., 2012). This process is also controlled by the Fe concentration. Dong et al. (2016) found that the concentration of Fe-modified biochar addition could enhance the biomass of cabbages. In this study, however, the dry weight of the cabbage was not influenced by Fe-modified biochar supplementation. In addition, biochar contains a porous structure that can adsorb more water and prevent the loss of nutrients needed for plant growth in the soil (Dong et al., 2016). This could explain why the fresh weight of the cabbages increased when they were treated with BC and FMB addition. In summary, FMB concentrations of $0.5 \%$ for the three amendments were suitable for cabbage growth in As/Cd-contaminated soil and did not cause iron poisoning.

\section{Conclusions}

The results of column experiment indicated that the addition concentration of $0.5 \%$ in the three soil amendments was most suitable for As and $\mathrm{Cd}$ co-contaminated soils based on characteristics of economy and efficiency. The total As and Cd concentrations in the cabbages were significantly lower under FMB addition than in the control group. Additionally, FMB significantly increased the residual As and Cd concentrations in the soil, indicating that the FMB had the best effect on the immobilization of As and Cd in the soil. Furthermore, FMB had no ill effect on cabbage growth under the experimental concentration. Therefore, $0.5 \%$ FMB demonstrated great potential application in the treatment of As/Cd-contaminated soil. FMB as a soil amendment is one of the development directions of soil remediation or soil stabilization, and its cost and process safety need to be further evaluated and studied.

Funding. This research was sponsored by the National Science Foundation of China (41867022; 21707024), the Special Funds of Guangxi Distinguished Experts, and Program for High Level Innovation Team and Outstanding Scholar of Universities in Guangxi (GuiCaiJiaoHan[2018]319), Guilin Science and Technology Development Program (20190219-3), Key Laboratory of Ecology of Rare and Endangered Species and Environmental Protection (Guangxi Normal University), Ministry of Education, China (ERESEP2018K03).

\section{REFERENCES}

[1] Al-Abed, S. R., Jegadeesan, G., Purandare, J., Allen, D. (2007): Arsenic release from iron rich mineral processing waste: influence of $\mathrm{pH}$ and redox potential. - Chemosphere 66: 775-782.

[2] Amstaetter, K., Borch, T., Casanova, P. L., Kappler, R. (2010): Redox transformation of arsenic by $\mathrm{Fe}(\mathrm{II})$-activated goethite (a-FeOOh). - Environ. Sci. Technol. 44: 102-108.

[3] Bashir, S., Hussain, Q., Shaaban, M., Hu, H. Q. (2018): Efficiency and surface characterization of different plant derived biochar for cadmium (Cd) mobility, bioaccessibility and bioavailability to Chinese cabbage in highly contaminated soil. Chemosphere 211: 632-639. 
[4] Beesley, L., Marmiroli, M., Pagano, L., Pigoni, V., Fellet, G., Fresno, T., Vamerali, T., Bandiera, M., Marmiroli, N. (2013): Biochar addition to an arsenic contaminated soil increases arsenic concentrations in the pore water but reduces uptake to tomato plants (Solanum lycopersicum L.). - Sci. Total. Environ. 454-455: 698-603.

[5] Bian, R. J., Joseph, S., Cui, L. Q., Pan, G. X., Li, L. Q., Liu, X. Y., Zhang, A., Rutlidge, H., Wong, S. W., Chia, C., Marjo, C., Gong, B., Munroe, P., Donne, S. (2014): A threeyear experiment confirms continuous immobilization of cadmium and lead in contaminated paddy field with biochar amendment. - J. Hazard. Mater. 272: 121-128.

[6] Dong, S. K., Xu, W. L., Wu, F. F., Yan, C. X., Li, D. P., Jia, H. T. (2016): Fe-modified biochar improving transformation of arsenic form in soil and inhibiting its adsorption of plant. - Transaction of the Chinese Society of Agricultural Engineering 32(15): 204-212.

[7] Glaser, B., Lehmann, J., Zech, W. (2002): Ameliorating physical and chemical properties of highly weathered soils in the tropics with charcoal: a review. - Biol. Fert. Soils 35(4): 219-230.

[8] Irshad, M. K., Noman, A., Alhaithloul, H. A. S., Adeel, M., Rui, Y., Shah, T., Zhu, S., Shang, J. (2020): Goethite-modified biochar ameliorates the growth of rice (Oryza sativa L.) plants by suppressing $\mathrm{Cd}$ and As-induced oxidative stress in $\mathrm{Cd}$ and $\mathrm{As}$ cocontaminated paddy soil. - Sci. Total. Environ. 717.

[9] Kloke, A., Sauerbeck, D. R., Vetter, H. (1984): The Contamination of Plants and Soils with Heavy Metals and the Transport of Metals in Terrestrial Food Chains. - In: Nriagu, J. (ed.) Changing Metal Cycles and Human Health. Springer, Berlin, pp. 113-141.

[10] Kumarathilaka, P., Seneweera, S., Meharg, A., Bundschuh, J. (2018): Arsenic speciation dynamics in paddy rice soil-water environment: sources, physico-chemical, and biological factors-A review. - Water Res.140: 403-414.

[11] Li, H., Li, Y. W., Cai, Q. Y., Li, H. Y., Mo, C. H., Wong, M. H. (2017): Cadmium in rice: transport mechanisms, influencing factors, and minimizing measures. - Environ. Pollut. 224: 622-630.

[12] Liang, J., Yang, Z. X., Tang, L., Zeng, G. M., Yu, M., Li, X. D., Wu, H. P., Qian, Y. Y., Li, X. M., Luo, Y. (2017): Changes in heavy metal mobility and availability from contaminated wetland soil remediated with combined biochar-compost. - Chemosphere 181: 281-288.

[13] Liu, J., Mo, L. Y., Zhang, X. H., Yao, S. Y., Wang, Y. X. (2018): Simultaneous hyperaccumulation of cadmium and manganese in Celosia argentea Linn. - Int $\mathrm{J}$ Phytoremediat 20(11): 1106-1112.

[14] Mladenov, N., Zheng, Y., Miller, M. P., Nemergut, D. R., Legg, T., Simone, B., Hageman, C., Rahman, M. M., Ahmed, K. M., Mchnight, D. M. (2010): Dissolved organic matter sources and consequences for iron and arsenic mobilization in Bangladesh aquifer. - Environ. Sci. Technol. 44(1): 123-128.

[15] Nakanishi, H., Ogawa, I., Ishimaru, Y., Mori, S., Nishizawa, N. K. (2006): Iron deficiency enhances cadmium uptake and translocation mediated by the $\mathrm{Fe}^{2+}$ transporters OsIRT1 and OsIRT2 in rice. - Soil Sci. Plant Nutr. 52: 464-469.

[16] Park, J. H., Choppala, G. K., Bolan, N. S., Chung, J. W., Chuasacathi, T. (2011): Biochar reduces the bioavailability and phytotoxicity of heavy metals. - Plant Soil 348: 439-451.

[17] Pedersen, H. D., Postma, D., Jakobsen, R. (2006): Release of arsenic associated with the reduction and transformation of iron oxides. - Geochim. Cosmochim. Ac. 70(16): 41164129.

[18] Qiao, J. T., Liu, T. X., Wang, X. Q., Li, F. B., Lv, Y. H., Cui, J. H., Zeng, X. D., Yuan, Y. Z., Liu, C. P. (2018a): Simultaneous alleviation of cadmium and arsenic accumulation in rice by applying zero-valent iron and biochar to contaminated paddy soils. Chemosphere 195: 260-271.

[19] Qiao, J. T., Li, X. M., Hu, M., Li, F. B., Young, L. Y., Sun, W. M., Huang, W. L., Cui, J. H. (2018b): Transcriptional activity of arsenic-reducing bacteria and genes regulated by 
lactate and biochar during arsenic transformation in flooded paddy soil. - Environ. Sci. Technol. 52: 61-70.

[20] Rocco, C., Seshadri, B., Adamo, P., Bolan, N. S., Mbene, K., Naidu, R. (2018): Impact of waste-derived organic and inorganic amendments on the mobility and bioavailability of arsenic and cadmium in alkaline and acid soils. - Environ. Sci. Pollut. R. 25: 2589625905.

[21] Ryu, D. J., Oh, R. G., Seo, Y. D., Oh, S. Y., Ryu, K. S. (2015): Recovery and electrochemical performance in lithium secondary batteries of biochar derived from rice straw. - Environ. Sci. Pollut. Res. 22: 10405-10412.

[22] Sneath, H. E., Hutchings, T. R., de Leij, F. A. A. M. (2013): Assessment of biochar and iron filing amendments for the remediation of a metal, arsenic and phenanthrene cocontaminated spoil. - Environ. Pollut. 178: 361-366.

[23] Sun, T., Levin, B. D. A., Guzman, J. J. L., Enders, A., Muller, D. A., Angenent, L. T., Lehmann, J. (2017): Rapid electron transfer by the carbon matrix in natural pyrogenic carbon. - Nat. Commun. 14873.

[24] Tessier, A., Campbell, P. G. C., Bisson, M. (1979): Sequential extraction procedure for the speciation of particulate trace metals. - Anal. Chem. 51(7): 844-851.

[25] Venegas, A., Rigol, A., Vidal, M. (2016): Changes in heavy metal extractability from contaminated soils remediated with organic waste or biochar. - Geoderma 279(1): 132140.

[26] Warren, G. P., Alloway, B. J., Lepp, N. W., Singh, B., Bochereau, F. J. M., Penny, C. (2003): Field trials to assess the uptake of arsenic by vegetables from contaminated soils and soil remediation with iron oxides. - Sci. Total. Environ. 311: 19-33.

[27] Wen, E., Yang, X., Chen, H., Shaheen, S. M., Sarkar, B., Xu, S., Song, H., Liang, Y., Rinklebe, J., Hou, D., Li, Y., Wu, F., Pohorely, M., Wong, J. W. C., Wang, H. (2020): Iron-modified biochar and water management regime-induced changes in plant growth, enzyme activities, and phytoavailability of arsenic, cadmium and lead in a paddy soil. - J. Hazard. Mater. 124344.

[28] Wenzel, W. W., Kirchbaumer, N., Prohaska, T., Stingeder, G., Lombi, E., Adriano, D. C. (2001): Arsenic fraction in soils using an improved sequential extraction procedure. Anal. Chim. Acta. 436: 309-323.

[29] Wu, S. X., Wang, X., Chen, C., Bo. P., Tan, C. Y., Zhang, F., Xu, Y. Q., Zhuang, Y. J. (2015): Characterization of biochar derived from water hyacinth, rice straw and sewage sludge and their environmental implications. - Acta Sci. Circum. 35.

[30] Wu, Y., Kukkadapu, R. K., Livi, K. J. T., Xu, W. Q., Li, W. (2018): Iron and arsenic speciation during As(III) oxidation by manganese oxides in the presence of $\mathrm{Fe}(\mathrm{II})$ : molecular-level characterization using XAFS, Mössbauer, and TEM analysis. - Acs Earth Space Chem. 2: 256-268.

[31] Xiao, Y. K., Yu, H. Y., Li, J. M., Zhang, Y. P. (2012): Effect of concentration of iron element in aeroponic cultivation on photosynthesis and yield of potato minituber. Transactions of the Chinese Society for Agriculture Machinery 43(10): 195-199.

[32] Xu, X. W., Chen, C., Wang, P., Kretzschmar, R., Zhao, F. J. (2017): Control of arsenic mobilization in paddy soils by manganese and iron oxides. - Environ. Pollut. 231: 37-47.

[33] Yin, D. X., Wang, X., Peng, B., Tan, C. Y., Ma, L. Q. (2017): Effect of biochar and Febiochar on $\mathrm{Cd}$ and As mobility and transfer in soil-rice system. - Chemosphere 186: 928937.

[34] Yu, H. Y., Liu, C. P., Zhu, J. S., Li, F. B., Deng, D. M., Wang, Q., Liu, C. S. (2016a): Cadmium availability in rice paddy fields a mining area: the effects of soil properties highlighting iron fractions and $\mathrm{pH}$ value. - Environ. Pollut. 209: 38-45.

[35] Yu, H. Y., Liu, C. S., Huang, W., Liu, T. X., Yu, W. M. (2016b): Chapter five- iron redox cycling coupled to transformation and immobilization of heavy metals: implications for paddy rice safety I the red soil of south China. - Adv Agron. 137: 279-317. 


$$
-4780-
$$

[36] Yu, H. Y., Wang, X. Q., Li, F. B., Li, B., Liu, C. P., Wang, Q., Lei, J. (2017): Arsenic mobility and bioavailability in paddy soil under iron compound amendments at different growth stages of rice. - Environ. Pollut. 224: 136-147.

[37] Yu, G., Long, Y. M., Chen, Z., Sunahara, G. I., Jiang, P. P., You, S. H., Lin, H., Xiao, H. (2020): Phytoextraction of cadmium-contaminated soils: comparison of plant species and low molecular weight organic acids. - Int. J. Phytoremediat. 22(4): 383-391.

[38] Zhang, H., Shao, J., Zhang, S., Zhang, X., Chen, H. (2020): Effect of phosphorusmodified biochars on immobilization of $\mathrm{Cu}$ (II), Cd (II), and As (V) in paddy soil. - J. Hazard. Mater. 390.

[39] Zhao, F. J., Ma, Y. B., Zhu, Y. G., Tang, Z., McGrath, S. (2015): Soil contamination in China: current status and mitigation strategies. - Environ. Sci. Technol. 49: 750-759.

[40] Zhu, Z. Q., Huang, C. P., Zhu, Y. Q., Wei, W. H., Qin, H. (2018): A hierarchical porous adsorbent of nano-a- $\mathrm{Fe}_{2} \mathrm{O}_{3} / \mathrm{Fe}_{3} \mathrm{O}_{4}$ on bamboo biochar (HPA-Fe/C-B) for the removal of phosphate from water. - J. Water Process Eng. 25: 96-104. 